\title{
Betty Tillman, a remembrance of times long ago
}

\author{
Richard E. Wagner
}

Published online: 13 November 2013

(C) Springer Science+Business Media New York 2013

It was in 1962 that Betty Tillman started working for Jim Buchanan. I moved to Charlottesville to start graduate school in 1963, so my memories of Betty and of Jim span 50 years. In these remarks I shall focus on the first ten or so years, for it was then that my impressions of her were formed and which remained with me ever after. Those impressions were rooted in warmth, graciousness, and generosity. Betty came into my life even before I met her. Before my wife and I left Los Angeles for Charlottesville in late August, Betty dropped me a note saying that I should get in touch with her once I arrived in Charlottesville. That I did and was glad to have done it because she put us in touch with a real estate agent who found my wife and I the place we lived in for the next three years.

While my three years in Charlottesville were that of a harried graduate student who was eager to finish the program, Betty frequently offered friendly words of encouragement. Betty's work space was at the end of a corridor in the basement of Rouss Hall, where the suite of offices of the Thomas Jefferson Center was located. Jim Buchanan's and Gordon Tullock's offices flanked Betty's space, and when you entered the Center she invariably had cheerful words for you, offering a nice respite from the arduous work that the faculty typically assigned to students.

Her cheerfulness was matched by her generosity. The University of Virginia offered only a June graduation at that time, and also required students to march in Commencement to receive their degrees. I had accepted a job at the University of California, Irvine, and did not want to return to Charlottesville to graduate in 1967. So I had to graduate in 1966, which meant that I had to submit my dissertation by the first Friday in May as I recall. Over the preceding few days, my wife and I worked in shifts keeping our IBM Selectric going in a frantic rush to submit my dissertation on time. Betty knew my situation, and either that Thursday evening or the Friday morning, she called to see how I was doing. When I told her that I just didn't think I could submit it before five, she asked if I thought it could be ready before noon on Saturday. I said yes. She then said she would wait for me to give it to

R.E. Wagner $(\bowtie)$

Department of Economics, George Mason University, Fairfax, VA 22030, USA

e-mail: rwagner@gmu.edu 
her at the office Saturday morning, for she could arrange for it to be treated as having been submitted in timely fashion. So my stay in Charlottesville began with a kind act from Betty, and ended in the same way.

Seven years after leaving Charlottesville, my wife and I and our two daughters moved to Blacksburg. Once again, Betty took an active role in helping us to get settled, and invariably was a warm presence around the office once I was ready to get back to work. As a faculty member I was more fully aware of the visitors who came through the Public Choice Center than I was as a student in Charlottesville, where mostly all I knew of those visitors was from attending the seminars they gave. It was during this time in Blacksburg that the Public Choice Center and the Public Choice Society were leaving behind their formative stages and moving into maturity. It was in that context that I realized that Betty offered a type of flying buttress to Jim Buchanan's scholarly work. While Jim's work spoke loudly for him in its own right, to most people Jim was more aloof and taciturn than warm. By contrast, Betty projected warmth and friendliness wherever she went and toward whomever she met. It is with no fear of contradiction that I can assert that Betty Tillman added positive value to the reputation of the Public Choice Center in its early days. The same assertion could be made for more recent times, but I have chosen to limit my remarks to those comparatively ancient times about which few other people have first-hand knowledge. 